\title{
Brassinosterioids Stimulate Nitrogen Metabolism of Pigeon Pea Plants under Water Deficit Conditions
}

\author{
Sujatha Edupuganti, Shahana Tahinyath, Anusha
}

\begin{abstract}
This study was aimed to find the effects of 28-epibrassinolide (28-EBL) and HBL on pigeon pea seedlings subjected to drought stress, either alone and supplemented with 28-EBL and HBL treatments. Supplementation of EBL $(2 \mu M)$ and $\mathrm{HBL}(2 \mu \mathrm{M})$ alone also exhibited the significant improvement in nodule number, nodule fresh weight, nodule dry weight, nodule Leghemoglobin content, root nodule nitrogenase (N2ase)under stress free conditions but under Drought stress conditions $E B L(2 \mu M)$ and $H B L(2 \mu M)$ exhibited the significant improvement in nodule number, nodule fresh weight, nodule dry weight, nodule leghemoglobin content, root nodule nitrogenase (N2ase) while as control and other concentration $(0.5,1 \mu M)$ didn't performed up to level. Effect of Brassinosteroids increase the root nitrate reductase $(N R)$, root nitrite reductase (NiR) activity, root nitrate (NO3-) content, root nitrite (NO2-) content, GS enzymes activities, under stress free conditions, under drought stress conditions this activity is ultimately low. Brassinosteroids at all concentration exhibited positive correlation with significantly raise in the root ammonium (NH4+) content and GOGAT enzymes activities. The present study shows that Pigeon pea plants under water stress, stimulate nitrogen metabolism effecting enzymes associated with it. But different concentration of 28-epibassinolide $(0.5,1,2 \mu M)$ and $H B L$ were applied to the crop under drought stress- and stress-free conditions. Exogenous application of EBL and $\mathrm{HBL}$ promotes the Nitrogen Metabolism as plotted in the Graphs Further research is required for the detailed analysis.
\end{abstract}

Keywords: EBL, HBL, nitrogen metabolism, stress free conditions, Drought stress conditions.

\section{INTRODUCTION}

up take of essential nutrients $(\mathrm{N}, \mathrm{P}, \mathrm{K}, \mathrm{Ca}$, $\mathrm{Mg}, \mathrm{Fe}, \mathrm{Mn}, \mathrm{Cu}, \mathrm{Zn}$ and so forth.) is additionally significant for plant growth. Higher ion influx permits expanded effectiveness of light vitality transformation, $\mathrm{CO} 2$ conductivity, capability of light and dull reactions, and photosynthetic rate $[2,4]$. An ongoing report detailed that $B R$ expanded essential inorganic ions, decreased toxic ions, and advanced ion homeostasis particularly in leaves, root, and epicotyl of canola under salt stress [1]. Diminishing the hurtful impact of

Revised Manuscript Received on October 15, 2019.

* Correspondence Author

Sujatha Edupuganti, Department of Botany, University College of Science, Osmania University, Hyderabad, Telangana, India.

Shahana Tahinyath, Department of Botany, University College of Science, Telangana University, Dichpally, Nizamabad, Telangana, India.

Anusha, Department of Botany, University College of Science, Telangana University, Dichpally, Nizamabad, Telangana, India.

low temperature and feeble light stress, 24-epibrassinolide upgraded nitrogen digestion; the movement of nitrate reductase (NR), nitrite reductase (NiR), glutamine synthetase (GS), glutamate synthase (GOGAT) and glutamate dehydrogenase (GDH) chemicals, and incited photosynthetic qualities of tomato seedlings [3]. Moreover, exogenous BR application expanded $\mathrm{H}+$-ATPase and $\mathrm{Ca} 2+-\mathrm{ATPase}$ exercises in root and leaf [5], which are in charge of building up an electrochemical potential inclination to keep up ion balance in plants to ease stress impact.

The induced inhibition of development brought about by low temperature and feeble light conditions might be engaged with a few physiological dysfunctions, including the reduction of photosynthetic efficiency, inhibition of biological carbon and nitrogen fixation, generation of receptive oxygen species (ROS), and layer lipid peroxidation $(6,7)$. 24-epibrassinolide (EBR) is a biologically dynamic mixes of the brassinosteroids that assumes a basic job in a wide cluster of crucial procedures at nano-molar to micro-molar concentrations, including cell division, elongation, vascular differentiation, and the regulation of gene expression levels. EBR likewise influences other developmental procedures, for example, the germination of seeds, root and stem development, organic product improvement, senescence, abscission, and development (8, 9). Numerous investigations have demonstrated that EBR could present protection from plants against different abiotic and biotic burdens, for example, dry season pressure (10), blended saltiness temperature stress (11), heat pressure (12), salt pressure (13), cadmium stress (14), phenanthrene stress (15), and $\mathrm{Ca}$ (NO3)2 stress (16). Recently, several concentrates demonstrated that foliar application of EBR could upgrade plant resilience to various burdens by means of improving photosynthetic capacity, essentially inferable from an expansion in the chlorophyll (Chl) content, and the up-guideline in the expression levels of different oxidative pressure marker genes $(17,16)$. 


\section{Brassinosterioids Stimulate Nitrogen Metabolism of Pigeon Pea Plants under Water Deficit Conditions}

Despite the fact that the EBR applications under typical conditions additionally advanced plant development, improved the net photosynthetic rate, and expanded cell reinforcement framework capacity, the impacts of EBR on plants under the salt-focused on conditions were more unmistakable than those under non-salt-focused on conditions (16). Those discoveries demonstrated that EBR reacted to different worries by actuating diverse physiological and atomic components. In any case, little data is thought about the job of EBR in the plant's reaction to the combined worry of low temperature and powerless light. ensured vegetable development is much of the time presented to imperfect temperatures (beneath $18 \quad \mathrm{C} / 8$ $\mathrm{C}$,day/night) and feeble light force attributable to unfriendly climate conditions, including mists, downpour, mist or murkiness. The distributed writing has improved our comprehension of the multifaceted jobs of EBR in the photosynthesis of higher plants under different natural conditions $(9,18,16)$, however less is known in regards with the impacts of exogenous EBR medications on the photochemical efficiency and nitrogen digestion of tomato seedlings presented to low temperature and feeble light conditions. In the present investigation, we inspected the impacts of a combined low temperature and feeble light worry, with and without EBR, on development, gas exchange parameters, chlorophyll fluorescence imaging, and nitrogen digestion in tomato leaves. The goal was to explain the physiological jobs of EBR in lightening the hurtful consequences for plant development induced by a combined low temperature and frail light pressure.

\section{MATERIALS AND METHODS}

\section{1) Nitrogen Metabolism}

Nodule number, nodule fresh weight and nodule dry weight:

Nodules formed were visually observed for their size and colour. Symbiotic development by Rhizobium was estimated by counting total nodule number per root system (Figure 1), nodule fresh weight (Figure 2)and measuring total nodule dry weight per root system (Figure 3).

a) Leghemoglobin ( $\mathrm{LHb})$ in nodules: Sadasivan and Manickam, (1992)

The nodules were detached immediately after sampling and their $\mathrm{LHb}$ concentration was determined by the method of Sadasivam and Manickam, (1992), which is based upon the conversion of hematin to pyridine hemochromogen (Figure 4)

Extraction

$500 \mathrm{mg}$ of fresh nodular tissue was homogenized in $5 \mathrm{ml}$ of $0.05 \mathrm{M}$ phosphate buffer ( $\mathrm{pH}$ 7.0). The homogenate was filtered through two layers of cheesecloth. The nodule debris was discarded, and the turbid reddish brown filtrate was centrifuged at $10,000 \mathrm{~g}$ for 30 minutes.

Procedure: A $3 \mathrm{ml}$ aliquot of alkaline pyridine reagent was added to $3 \mathrm{ml}$ of nodule extract and mixed well; the solution became greenish yellow due to the formation of hemochrome. The hemochrome was divided equally into two test tubes. To one test tube, a few crystals of potassium hexacyanoferrate were added to oxidize the hemochrome, and the absorbance was measured at $539 \mathrm{~nm}$ using a spectrophotometer (Spectronic 20D, Milton Roy, USA). To the other test tube, a few crystals of sodium dithionite were added to reduce the hemochrome, and the absorbance of this mixture was measured at $556 \mathrm{~nm}$ after an interval of 25 minutes. The leghemoglobin content (mM) was calculated using the followingformula:

Lb concentration $(\mathrm{mM})=$ A556-A539/23.4× 2D

where $\mathrm{D}$ is the initial dilution and A556 and A539 are the absorbance at 556 and $539 \mathrm{~nm}$, respectively.

b) Nitrogenase (EC 1.18.6.1) activity in the nodules: Herdina and Silsbury, (1990)

Nitrogenase activity in nodules was measured using the acetylene reduction method as outlined by Herdina and Silsbury, (1990). The nitrogen-fixing complex (nitrogenase) of legumes is able to reduce $\mathrm{C} 2 \mathrm{H} 2$ to $\mathrm{C} 2 \mathrm{H} 4$. The assay was performed immediately after harvesting the plants. The nodulated roots were cut from the base and shaken slowly in water to remove the attached soil particles and was incubated at room temperature in vials containing acetylene $(\mathrm{C} 2 \mathrm{H} 210$ percent, v/v) in air and sealed with serum caps. The samples were flushed with acetylene gas by gently shaking the bottles and were incubated for $1 \mathrm{hr}$. The sample of $1 \mathrm{ml}$ of gas from the incubation mixture was analyzed for ethylene in a Shimadzu GC-14B gas chromatograph equipped with a Porapak $\mathrm{R}$ column (Ligero et al., 1986). Although the use of such a "closed" system for measuring acetylene reduction does create problems related to an acetylene induced decline in nitrogenase activity (Minchin et al., 1983), it is still useful for comparative purposes, especially when the assay time is short (Vessey, 1994). From the standard values, the number of moles of ethylene produced in each case was calculated and the rate of ARA was calculated as number of $\mathrm{C} 2 \mathrm{H} 4$ moles produced per mg dry weight of nodules per hr (nmolC2H4 mg-1 nodule DW. hr-1) (Figure 7). 
2) Extraction and assay of nitrate reductase and nitrite reductase activity:

Approximately $0.5 \mathrm{~g}$ of the frozen root material was ground into a fine powder in an ice bath. The powder was extracted in $4 \mathrm{ml}$ of ice-cold extraction buffer containing $25 \mathrm{mM}$ potassium phosphate buffer ( $\mathrm{pH}$ 7.5), $5 \mathrm{mM}$ cysteine and $5 \mathrm{mM}$ EDTA-Na2. The extract was centrifuged at $4,000 \mathrm{rpm}$ for $15 \mathrm{~min}$ at $4^{\circ} \mathrm{C}$.

a) Nitrate Reductase (NR, E.C.1.6.6.1): Jaworski, (1971)

Nitrate reductase was determined following the in vivo method described by Jaworski, (1971). Roots from different treatments were taken separately and were cut into small pieces. About $0.5 \mathrm{gm}$ of root material was incubated in the medium containing $1 \mathrm{ml}$ of $1 \mathrm{M}$ potassium nitrate, 2 $\mathrm{ml}$ of $0.5 \%$ Triton $\mathrm{X}-100$ for 1 hour, in dark under anaerobic conditions. After one-hour, $1 \mathrm{ml}$ reaction mixture was transferred to another test tube and mixed with $1 \mathrm{ml}$ of $1 \%$ sulfanilamide in $2 \mathrm{~N}$ hydrochloric acid and $1 \mathrm{ml}$ of $0.2 \%$ NEEDA (N-Cl-napthyl ethylene diamide dihydrochloride). $1 \mathrm{ml}$ sulfanilamide and $1 \mathrm{ml}$ NEEDA served as blank. The absorbance was read at $540 \mathrm{~nm}$ in SCHIMADZU UV-1800 Spectrophotometer. Standard curve was prepared with the help of different concentrations of potassium nitrite and enzyme activity was expressed as micromoles of NO2 liberated h-1 g-1 fresh weight (Figure 5)

b) Nitrite Reductase (NiR, EC 1.7.2.1): Miflin, (1967)

activity was measured as a reduction in the amount of NO2-in the reaction mixture according to Miflin, (1967) with slight modifications. The reaction mixture contained $0.1 \mathrm{M}$ potassium phosphate buffer ( $\mathrm{pH}$ 6.8), $0.4 \mathrm{mM}$ NaNO2, 2.3 $\mathrm{mM}$ methyl viologen, enzyme extract. The reaction was started by addition of $4.3 \mathrm{mM}$ sodium dithionite in $100 \mathrm{mM} \mathrm{NaHCO3.} \mathrm{The}$ reaction was incubated for $30 \mathrm{~min}$ at $27^{\circ} \mathrm{C}$ and was stopped by vigorously mixing the content of the assay tube on a vortexmixer until the methyl viologen was completely oxidized and boiling for $1 \mathrm{~min}$. The concentration of NO2remaining in the reaction mixture was determined at $540 \mathrm{~nm}$ after reaction with SA and NEDD as described above using a standard curve of known NaNO2 concentrations. One unit of NiR activity is defined as $1 \mathrm{mM}$ NO2- reduced mg-1 protein h-1.(Figure 6).

c) Nitrate: Cataldo et al., (1975)

Root samples were dried in an oven at $70 \mathrm{C}$ until constant weight was obtained. The dried material was ground to a powder and samples of $200 \mathrm{mg}$ were suspended in $10 \mathrm{ml}$ of

deionized water. The suspensions were incubated at $45 \mathrm{oC}$ for $2 \mathrm{~h}$. After mixing, the samples were centrifuged at $5,000 \quad \mathrm{X} g$ for 15 minutes, $0.2 \mathrm{ml}$ of supernatant was mixed thoroughly with $0.8 \mathrm{ml}$ of $5 \% \quad(\mathrm{w} / \mathrm{v})$ salicylic acid in concentrated $\mathrm{H} 2 \mathrm{SO} 4(\mathrm{SA}-\mathrm{H} 2 \mathrm{SO} 4)$. After incubation at room temperature for $20 \mathrm{~min}, 19 \mathrm{~mL}$ of $2 \mathrm{M} \mathrm{NaOH}$ was added to raise the $\mathrm{pH}$ to above 12. Samples were cooled to room temperature and NO3-concentration was measured by spectrophotometry at $410 \mathrm{~nm}$ with respect to its standard curve (Cataldo et al.,1975). The SA$\mathrm{H} 2 \mathrm{SO} 4$ reagent was made fresh at least once each week and stored in a brown bottle. Nitrate standards were stored at $4^{\circ} \mathrm{C}$ (Figure 8)

d) Nitrite: Ogawa et al., (1992)

The NO2- concentration in samples was quantified as described by Ogawa et al., (1992). Snap-frozen roots were ground to a fine powder under liquid nitrogen. About $100 \mathrm{mg}$ was extracted with a buffer containing $50 \mathrm{mM}$ TRIS-HCl (pH 7.9), $5 \mathrm{mM}$ cysteine, and $2 \mathrm{mM}$ EDTA. The amount of NO2- produced was measured by combining $500 \mu \mathrm{l}$ of the supernatant with $250 \mu \mathrm{l}$ of $1 \%$ sulfanylamide prepared in $1.5 \mathrm{~N} \mathrm{HCl}$ and $250 \mu \mathrm{l}$ of $0.02 \%$ $\mathrm{N}$-(1-naphtyl) ethylene-diamine dihydrochloride and reading at $540 \mathrm{~nm}$ in a spectrophotometer (Figure 9).

e) Ammonium: Brautigam et al., (2008a) Concentrations of $\mathrm{NH} 4+$ in the roots were calculated based on the Berthelot reaction according to Brautigam et al., (2008a). Roots were harvested and ground to a fine powder under liquid nitrogen. About $100 \mathrm{mg}$ of the powder was homogenized in $1 \mathrm{ml}$ of $100 \mathrm{mM}$ $\mathrm{HCl}$, and $500 \mu$ Lof chloroform. The samples were rotated for $15 \mathrm{~min}$ at $4{ }^{\circ} \mathrm{C}$, and the phases were separated by centrifugation at $10,000 \mathrm{~g}, \quad 4^{\circ} \mathrm{C}, \quad 10 \mathrm{~min}$. The aqueous phase was transferred to a fresh tube containing $50 \mathrm{mg}$ of acid-washed activated charcoal (activated charcoal), thoroughly mixed, and centrifuged $(20,000 \mathrm{~g}, 5$ $\left.\min , \quad 4^{\circ} \mathrm{C}\right)$. For ammonia quantification, the supernatant obtained after charcoal treatment was diluted 1:1 (v/v) in $100 \mathrm{mM} \mathrm{HCl}$. Then $20 \mu \mathrm{Lof}$ this solution is mixed with $100 \mu \mathrm{L}$ of a $1 \%$ (w/v) phenol-0.005\% (w/v) sodium nitroprusside solution in water, and $100 \mu \mathrm{L}$ of a $1 \% \quad(\mathrm{v} / \mathrm{v})$ sodium hypochlorite- $0.5 \%$ (w/v) sodium hydroxide solution in water was added. The samples were incubated at $37{ }^{\circ} \mathrm{C}$ for $30 \mathrm{~min}$, and absorbance was measured at $620 \mathrm{~nm}$ ( Figure 10)

Extraction and estimation of Glutamine synthetase (GS), Glutamine (amide) 2-oxoglutarate aminotransferase (GOGAT) and NADH specific Glutamate dehydrogenase (NADH-GDH) enzymes: 
About $0.3 \mathrm{~g}$ frozen root were powdered in liquid $\mathrm{N} 2$ and homogenized with $6 \mathrm{ml} 50 \mathrm{mM}$ Tris- $\mathrm{HCl}$ buffer $(\mathrm{pH} \quad 8.0)$ containing $2 \mathrm{mM}$ $\mathrm{Mg} 2+, 2 \mathrm{mM}$ DTT, and $0.4 \mathrm{M}$ sucrose. The homogenate was centrifuged at $8000 \mathrm{rpm}$ for 10 $\min$ at $4{ }^{\circ} \mathrm{C}$. The reactions were performed in $3 \mathrm{~mL}$ (final volume) of the media indicated below.

a) Glutamine synthetase (GS, EC 6.3.1.2): O' Neal and Joy, (1974)

The enzyme activity was determined as per the method of O'Neal and Joy, (1974) based on the formation of $\gamma$ - glutamylhydroxamate. The incubation mixture contained in a total volume of $3 \mathrm{ml}: \quad 0.6 \mathrm{ml}$ of imidazole-muriatic acid buffer $(0.25 \mathrm{M}, \mathrm{pH} 7.0), 0.4 \mathrm{ml}$ of glutamic acid-Na $(0.30 \mathrm{M}, \quad \mathrm{pH} \quad 7.0), \quad 0.4 \mathrm{ml}$ of ATP-Na (30 M, pH 7.0) and $0.2 \mathrm{ml}$ of MgSO4 (0.5 $\mathrm{M})$ and $1.2 \mathrm{ml}$ of extract. The mixture was incubated for $5 \mathrm{~min}$ at $25^{\circ} \mathrm{C}$. Subsequently, 0.2 $\mathrm{ml}$ of hydroxylamine hydrochloride (a 1:1 mixture of $1 \mathrm{M}$ hydroxylamine hydrochloride and $1 \mathrm{M}$ $\mathrm{HCl}$ ) was added, and the reaction was incubated for $15 \mathrm{~min}$ at $37^{\circ} \mathrm{C}$. The reaction was terminated by adding $0.8 \mathrm{ml}$ of acidic $\mathrm{FeCl} 3$ $(2 \%(\mathrm{~W} / \mathrm{V})$ in $\mathrm{TCA}$ and $3.5 \%(\mathrm{~W} / \mathrm{V}) \mathrm{FeCl} 3$ in $2 \% \mathrm{HCl})$. The reaction mixture was centrifuged at $4,000 \mathrm{rpm}$ for $15 \mathrm{~min}$ to remove precipitated proteins. The colour of ferric hydroxymate was measured at $540 \mathrm{~nm}$. The amount of $\gamma$ glutamylhydroxamate formed was determined through a comparison with a standard curve that was generated after measuring authentic glutamylhydroxamate in the presence of all assay components. One unit of GS activity was determined as the amount of enzyme required to catalyze the formation of $1 \quad \mu \mathrm{M}$ $\gamma$-glutamylhydroxamate $(\mathrm{GH}) / \mathrm{min}$ under the present conditions (Figure 11)

f) Glutamate synthase/ (Glutamine (amide) 2-oxoglutarate aminotransferase (GOGAT, EC 1.4.1.13): Singh and Srivasthava, (1987)

activity was measured according to the methods of Singh and Srivastava, (1987). Glutamate synthase activity was assayed at $30{ }^{\circ} \mathrm{C}$. In a $3 \mathrm{ml}$ final volume of reaction mixture consist of $10 \mu \mathrm{mol}$ a-ketoglutarate, $1 \mu \mathrm{mol}$ potassium chloride, $37.5 \mu$ molTris-HCl buffer ( $\mathrm{pH}$ 7.6), 0.6 $\mu \mathrm{mol} \mathrm{NADH}, 8 \mu \mathrm{mol}$ L-glutamine and $0.3 \mathrm{ml}$ enzyme. The absorbance of initial rate of oxidation of NADH was monitored for $300 \mathrm{~s}$ at $340 \mathrm{~nm}$. The activity of GOGAT was estimated using the molar extinction coefficient of NADH (6.22 $\mathrm{mM}-1 \cdot \mathrm{cm}-1)$ and expressed as nmol NADH•mg-1 Pro॰min-1 (Figure 12).

$\begin{array}{lcrr}\text { g) NADH } & \text { specific } & \text { glutamate } \\ \text { dehydrogenase/L-Glutamate } & \text { NAD-oxidoreductase }\end{array}$

(NADH-GDH, EC 1.4.1.2): Loulakakis and Rouelakis-Angelakis, (1990)

NADH-GDH activities were determined by the mehod of Loulakakis and Roubelakis-Angelakis, (1990). The $3 \mathrm{ml}$ reaction mixture consist of $300 \mu$ molTris-HCl buffer $(\mathrm{pH} 8.0), 600 \mu \mathrm{mol}$ ammonium chloride, $3 \mu \mathrm{mol}$ calcium chloride, $0.6 \mu \mathrm{mol}$ NADH, and $0.1 \mathrm{ml}$ enzyme. The reaction was started by adding enzyme extract and carried out at $30{ }^{\circ} \mathrm{C}$. The absorbance at $340 \mathrm{~nm}$ was monitored for $300 \mathrm{~s}$, and the activity of GDH was expressed as nmol NADH•mg-1Pro•min-1 (Figure 13).

\section{RESULTS}

Nodulation: Effect of BRs on nodule number, nodule fresh mass and dry mass in pigeon pea plants are presented in Figure 9.

Drought caused the significant loss in nodulation as evidenced by diminished nodule number $(41.2 \%$; $\mathrm{p}=0.046)$, fresh mass (45.1\%; $\mathrm{p}=0.027)$ and dry mass $(44.6 \% ; \mathrm{p}=0.030)$ compared with control. However exogenous application of BRs improved the nodulation response over the stress control. Application of EBL to drought stressed plants significantly increased the nodulation with maximum being at $2 \mu \mathrm{M}$ concentration where $79.1 \%, 67 \%$ and $77.4 \%$ enhancement in nodule number, nodule fresh mass and dry mass was observed as compared stressed control respectively. Similarly, HBL supplementation also recorded the significant improvement in nodule number, nodule fresh mass and dry mass in pigeon pea plants under water-deficit stress. BRs alone treatment also accounted for the considerable increase in nodulation compared with control. EBL at $2 \mu \mathrm{M}$ concentration showed the significant $(\mathrm{p} \leq 0.05)$ enhancement in nodule number, nodule fresh mass and dry mass; however compared to EBL the response of HBL alone on nodulation was insignificant.

Nitrogen fixation: Effect of BRs on nodule nitrogenase activity and leghaemoglobin (Lb) content in pigeon pea plants under drought stress are presented in Figure 9D \& 10C.

Nodule $\mathrm{N}_{2}$ ase activity was reduced to $37.16 \%(\mathrm{p} \leq 0.05)$ under water limited conditions. Foliar spray of EBL increased the $\mathrm{N}_{2}$ ase activity significantly with maximum response $(56.6 \%)$ being at $2 \mu \mathrm{M}$ concentration in drought stressed nodules. Similarly, HBL at $1 \mu \mathrm{M}$ concentration recorded the higher $\mathrm{N}_{2}$ ase activity (50.2\%) in drought stressed nodules over the stress control. At $2 \mu \mathrm{M}$ concentration both EBL and HBL alone treatments enhanced the $\mathrm{N}_{2}$ ase activity by $18 \%$ and $15.7 \%$ respectively compared with normal control.

The plants exposed to water limited condition (25\% SMC) had less Lb content (36.57\%; $\mathrm{p}=0.017)$ compared to control. Besides this, plants treated with exogenous EBL significantly increased the $\mathrm{Lb}$ content to the 
tune of $55.5 \%$ at $2 \mu \mathrm{M}$ concentration. Similarly, a significant enhancement (by 53.57\%) of Lb content was observed in Cajanus cajan under drought treated with $2 \mu \mathrm{M}$ HBL. BRs alone treatments also showed a considerable increase $\mathrm{Lb}$ content. Treatment with EBL and HBL alone increased the $\mathrm{Lb}$ content by $33.8 \%$ and $30 \%$ respectively at $1 \mu \mathrm{M}$ concentration over the control. The response on the $\mathrm{Lb}$ content between the EBL and HBL treatments was not significant $(\mathrm{p}=0.325)$.

Activity of enzymes involved in $\mathrm{NO}_{3}{ }_{3}$ reduction: Effect of BRs on root NR and NiR activities of pigeon pea plants under stress and stress free conditions are presented in Table Figure $10 \mathrm{~A} \& \mathrm{~B}$.

The NR activity sharply decreased in pigeon pea roots (68.8\%; $\mathrm{p}=0.023$ ) upon drought stress compared to control. Foliar spray of BRs counteracted the negative effects of drought stress on NR activity in pigeon pea. Exogenous EBL boosted the NR activity by $139.7 \%(p \leq 0.05)$ in water-deficit stress pigeon pea roots over the stress control. At $2 \mu \mathrm{M}$ concentration, HBL also had higher NR activity (128\%; $\mathrm{p}=0.022$ ) in drought stressed pigeon pea roots compared with stress control. It was noted that the NR activity was boosted considerably $(p \leq 0.05)$ in roots of pigeon pea receiving BRs alone.

Under drought stress, root NiR activity was statistically significantly reduced $(57.16 \%)$ in pigeon pea plants. However, application of both EBL and HBL to stressed plants stimulated the root $\mathrm{NiR}$ activity by $121.5 \%$ and $125 \%$ $(\mathrm{p} \leq 0.05)$ respectively compared with stress control. The response on the NiR activity between the EBL and HBL treatments was not significant $(121.5 \%$ vs $125 \%$; $\mathrm{p}=0.171)$. BRs alone treatments also promoted the NiR activities with maximum activity being recorded at $2 \mu \mathrm{M}$ concentration.

Accumulation of $\mathrm{NO}_{3}{ }^{-}, \mathrm{NO}_{2}{ }^{-}$and $\mathrm{NH}_{4}{ }^{+}$: Effect of BRs on the levels of carbohydrate fractions in pigeon pea plants under stress and stress free conditions are presented in Figure 11 .

In the roots of drought stressed pigeon pea plants $\mathrm{NO}_{3}{ }^{-}$and $\mathrm{NO}_{2}^{-}$levels diminished significantly by $38.9 \%$ and $46.2 \%$ respectively compared to control. Exogenous BRs spray alleviated the osmatic stress effects. EBL application elevated the root $\mathrm{NO}_{3}{ }^{-}$and $\mathrm{NO}_{2}{ }^{-}$levels significantly by $60.3 \%$ and $73.4 \% \quad(\mathrm{p} \leq 0.05)$ at $2 \mu \mathrm{M}$ concentration under water-deficit stress. Drought stressed plants receiving the $2 \mu \mathrm{M}$ HBL exhibited the promoted levels of $\mathrm{NO}_{3}{ }^{-}$and $\mathrm{NO}_{2}{ }^{-}$by $57.3 \%$ and $65 \%(\mathrm{p} \leq 0.05)$ respectively in roots. Pigeon pea plants showed the considerable accumulation of $\mathrm{NO}_{3}{ }^{-}$and $\mathrm{NO}_{2}{ }^{-}$in roots of BRs alone treatments compared to normal control.

Contrastingly, under drought stress, root $\mathrm{NH}_{4}^{+}$ levels were significantly accumulated by $23.3 \%(\mathrm{p}=0.041)$ compared with control. However, exogenous BRs as foliar spray further enhanced theroot $\mathrm{NH}_{4}{ }^{+}$levels $(30.1 \%$ by EBL) and $24.6 \%$ by $\mathrm{HBL} ; \mathrm{p} \leq 0.05)$ compared with stress control plants. BRs alone supplementation also accounted for the considerable enhancement of root $\mathrm{NH}_{4}{ }^{+}$levels $(18.8 \%$ by EBL and $12.53 \%$ by HBL) compared to control.

Activity of enzymes involved in $\mathrm{NH}_{4}{ }^{+}$utilization: Effect of BRs on root GS, GOGAT and NADH-GDH enzyme activities of pigeon pea plants under drought stress and stress free conditions are presented in Figure 12

The activities of root GS and GOGAT were declined by $48.4 \%$ and $25.1 \%(\mathrm{p} \leq 0.05)$ under drought stress in pigeon pea. However, exogenous supplementation of BRs to drought stressed plants alleviated the osmatic stress and improved these enzyme activities. EBL treatment at $2 \mu \mathrm{M}$ concentration showed the significant increase in GS $(85.3 \%)$ and GOGAT $(44.8 \%)$ activities in pigeon pea roots under drought stress compared with stress control. HBL also recorded the higher activities of root GS (70.6\%) and GOGAT (30.7\%) under drought conditions. The magnitude of EBL and HBL treatments on response of GS $(85.3 \%$ vs $70.6 \% ; \mathrm{p}=0.036)$ and GOGAT $(44.8 \%$ vs $30.7 \%$; $=0.045)$ activities were significant. The rootGS and GOGAT were also improved considerably in BRs alone treatments compared to control.

In contrast, drought stress increased the NADH-GDH activity by $23.2 \%(\mathrm{p} \leq 0.05)$ compared with control in pigeon pea roots. Foliar application of EBL further improved the NADH-GDH activity with maximum activity being at $1 \mu \mathrm{M}$ concentration by $17.75 \%$ compared with stress control. Exogenous HBL at $2 \mu \mathrm{M}$ concentration was found to be more effective with $16.6 \% \mathrm{NADH}-\mathrm{GDH}$ activity in pigeon pea roots over the stress control. Pigeon pea roots exhibited the significant enhancement in NADH-GDH activity $(23.73 \%$; $\mathrm{p}=0.032$ ) upon BRs alone treatments.

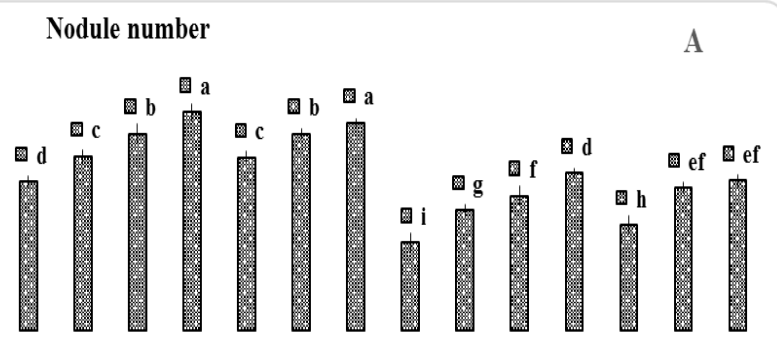

Figure 1: Effect of Brassinosteroids on nodule number of Cajanus cajan plants under drought stress- and stress-free conditions. Vertical bars represent means $\pm \mathrm{SE}(\mathrm{n}=5)$; Different letters on the top of bars denotes significant differences at $\mathrm{p} \leq 0.05$ according to Post Hoc Test 


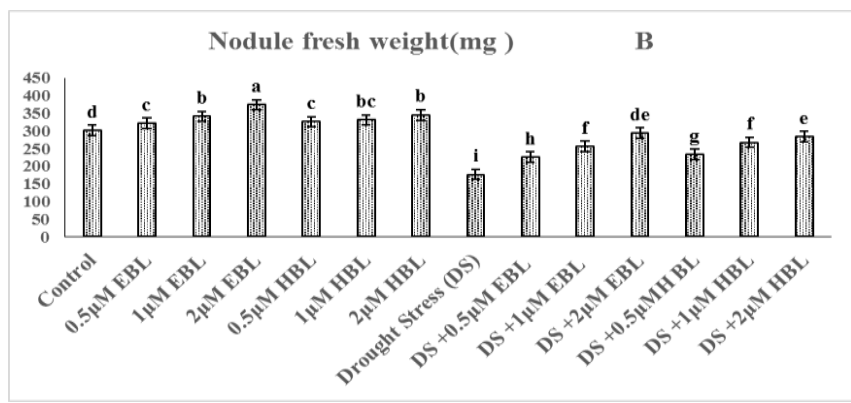

Figure 2: Effect of Brassinosteroids on nodule fresh weight of Cajanus cajan plants under drought stress- and stress-free conditions. Vertical bars represent means \pm SE $(n=5)$; Different letters on the top of bars denotes significant differences at $\mathrm{p} \leq 0.05$ according to Post Hoc Test

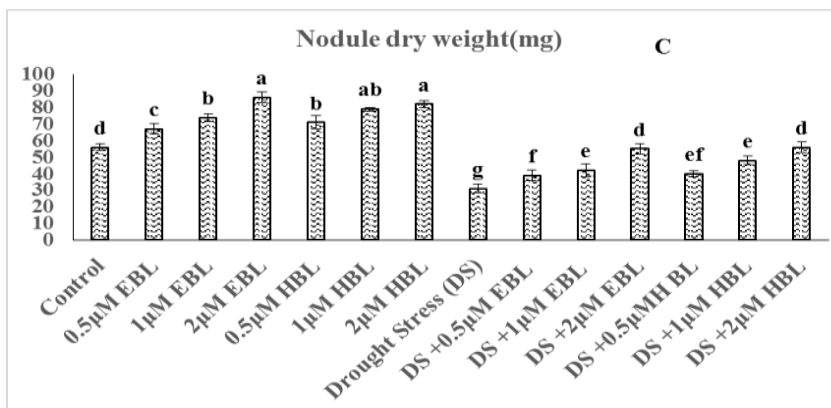

Figure 3: Effect of Brassinosteroids on nodule dry mass, content of Cajanus cajan plants under drought stress- and stress-free conditions. Vertical bars represent means \pm SE (n $=5$ ); Different letters on the top of bars denotes significant differences at $\mathrm{p} \leq 0.05$ according to Post Hoc Test

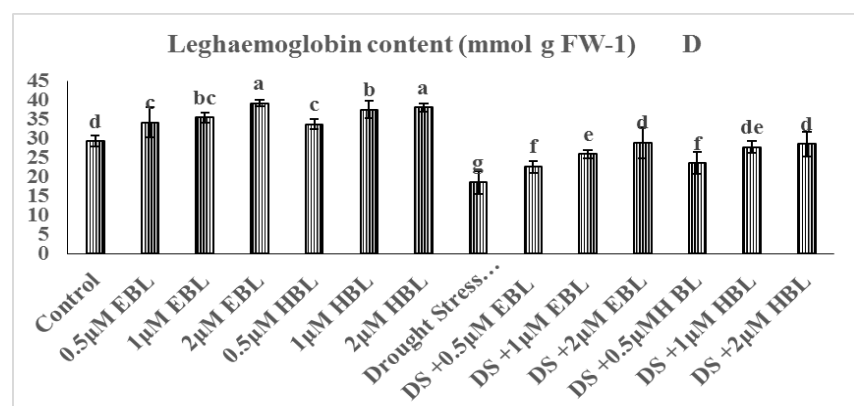

Figure 4: Effect of Brassinosteroids on nodule leghaemoglobin content of Cajanus cajan plants under drought stress- and stress-free conditions. Vertical bars represent means $\pm \operatorname{SE}(n=5)$; Different letters on the top of bars denotes significant differences at $\mathrm{p} \leq 0.05$ according to Post Hoc Test

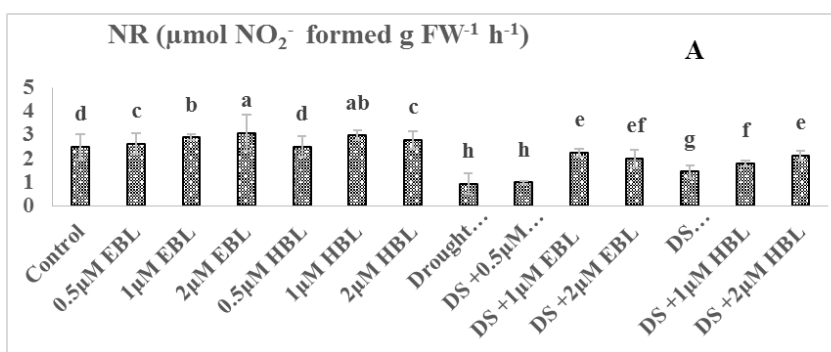

Figure 5: Effect of Brassinosteroids on root nitrate reductase (NR) activities of pigeon pea plants drought stress- and stress-free conditions. Vertical bars represent means \pm SE (n $=5$ ); Different letters on the top of bars denotes significant differences at $\mathrm{p} \leq 0.05$ according to Post hoc Test.

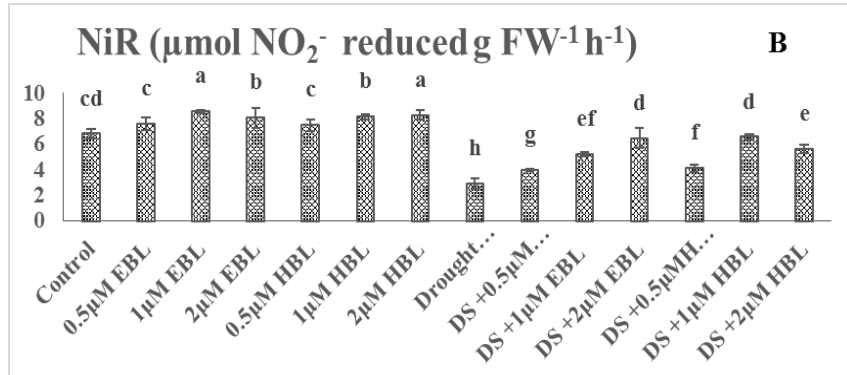

Figure 6: Effect of Brassinosteroids on root nitrite reductase $(\mathrm{NiR})$ activities of pigeon pea plants under drought stressand stress-free conditions. Vertical bars represent means \pm SE $(\mathrm{n}=5)$; Different letters on the top of bars denotes significant differences at $\mathrm{p} \leq 0.05$ according to Post hoc Test.

Nitrogenase ( $\mathrm{nmol} \mathrm{C}_{2} \mathrm{H}_{4} \mathrm{mg}^{-1}$ nodule DW. $\left.\mathrm{h}^{-1}\right)$

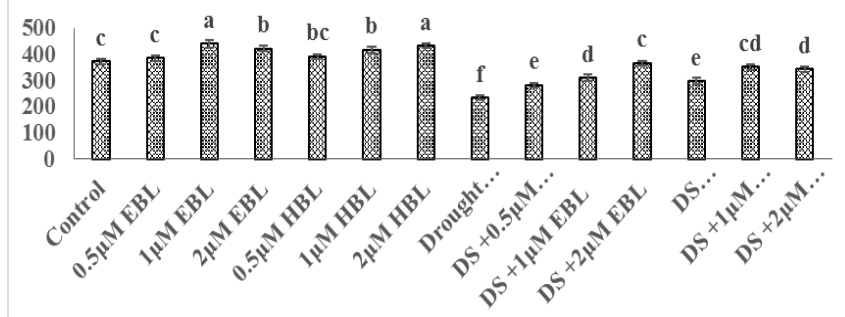

Figure 7: Effect of Brassinosteroids on root nodule nitrogenase $\left(\mathrm{N}_{2}\right.$ ase $)$ activities of pigeon pea plants under drought stress- and stress-free conditions. Vertical bars represent means $\pm \mathrm{SE}(n=5)$; Different letters on the top of bars denotes significant differences at $p \leq 0.05$ according to Post hoc Test.

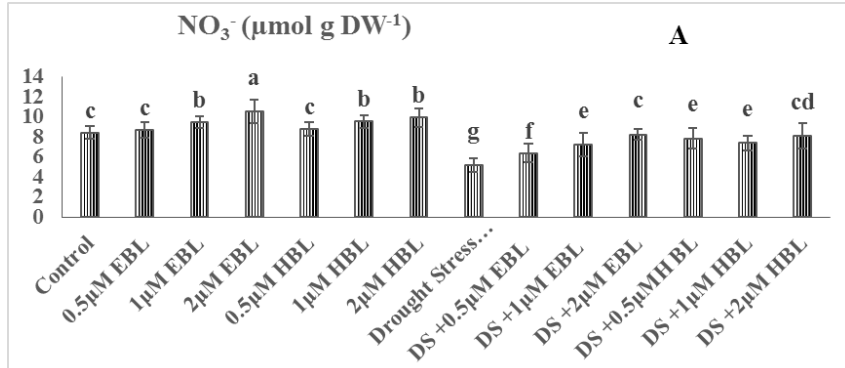

Figure 8: Effect of Brassinosteroids on root nitrate $\left(\mathrm{NO}_{3}{ }^{-}\right)$ content in Cajanus cajan plants under drought stress- and stress-free conditions. Vertical bars represent means \pm SE ( $n$ $=5$ ); Different letters on the top of bars denotes significant differences at $p \leq 0.05$ according to Post hoc Test.

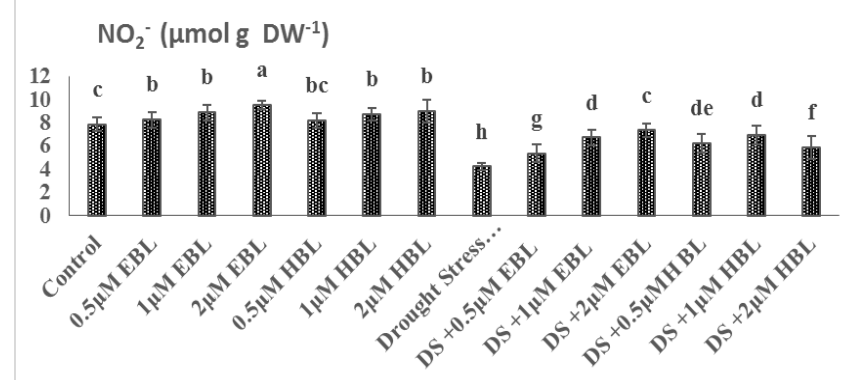

Figure 9: Effect of Brassinosteroids on root nitrite (NO2-) content in Cajanus cajan plants under drought stress- and stress-free conditions. Vertical bars represent means \pm SE (n $=5$ ); Different letters on the top of bars denotes significant differences at $\mathrm{p} \leq 0.05$ according to Post hoc Test. 


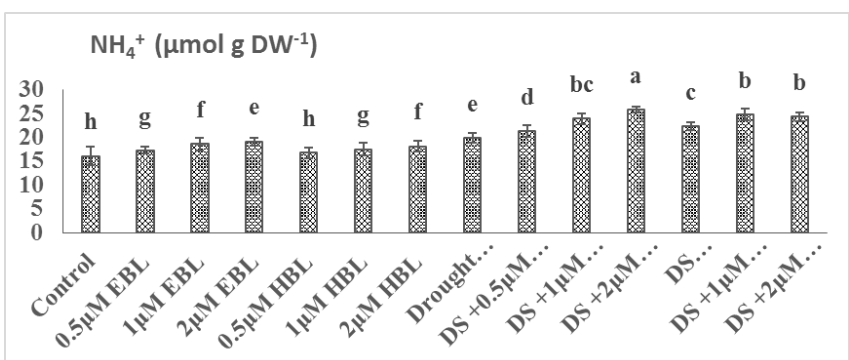

Figure 10: Effect of Brassinosteroids on root ammonium $\left(\mathrm{NH}_{4}{ }^{+}\right)$content in Cajanus cajan plants under drought stressand stress-free conditions. Vertical bars represent means $\pm \mathrm{SE}(n=5)$; Different letters on the top of bars denotes significant differences at $p \leq 0.05$ according to Post hoc Test.

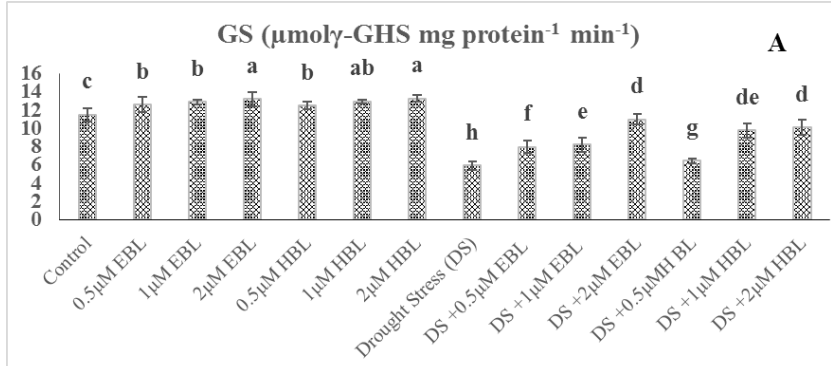

Figure 11: Effect of brassinosteroids on the GS enzymes activities of Cajanus cajan plants under drought stress- and stress-free conditions. Vertical bars represent means \pm SE (n = 5); Different letters on the top of bars denotes significant differences at $\mathrm{p} \leq 0.05$ according to Post hoc Test.

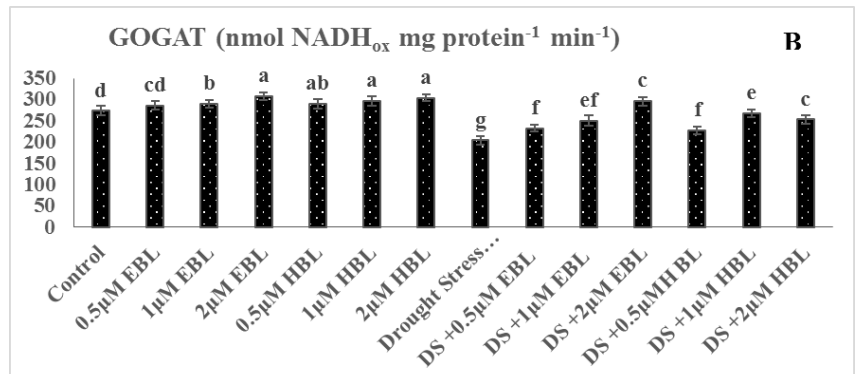

Figure 12: Effect of brassinosteroids on the GOGAT enzymes activities of Cajanus cajan plants under drought stress- and stress-free conditions. Vertical bars represent means $\pm \operatorname{SE}(n=5)$; Different letters on the top of bars denotes significant differences at $p \leq 0.05$ according to Post hoc Test.

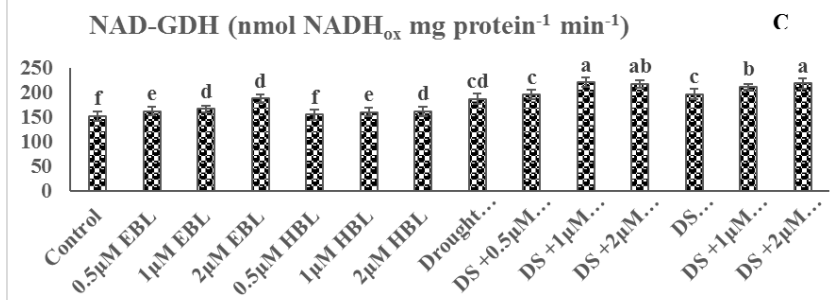

Figure 13: Effect of brassinosteroids on the NAD-GDH enzymes activities of Cajanus cajan plants under drought stress- and stress-free conditions. Vertical bars represent means \pm SE $(n=5)$; Different letters on the top of bars denotes significant differences at $\mathrm{p} \leq 0.05$ according to Post Hoc Test.

\section{CONCLUSION}

The present study shows that Pigeon pea plants under water stress, stimulate nitrogen metabolism effecting enzymes associated with it. But different concentration of 28-epibassinolide $(0.5,1,2 \mu \mathrm{M})$ and HBL were applied to the crop under drought stress- and stress-free conditions. Exogenous application of EBL and HBL promotes the Nitrogen Metabolism as plotted in the Graphs Further research is required for the detailed analysis.

\section{REFERENCES}

[1] 50. Steber CM, Mccourt P. 2001. A role for brassinosteroids in germination in Arabidopsis. Plant Physiol.; 125:763-769.

[2] Ahammed, G.J., Zhou, Y.H., Xia, X.J., Mao, W.H., Shi, K., Yu, J.Q., 2013. Brassinosteroid regulates secondary metabolism in tomato towards enhanced tolerance to phenanthrene. Biol. Plant. 57: 154-158.

[3] Bräutigam A, Hofmann-Benning S, Weber APM (2008a) Comparative proteomics of chloroplast envelopes from C3 and C4 plants reveals specific adaptations of the plastid envelope to $\mathrm{C} 4$ photosynthesis and candidate proteins required for maintaining $\mathrm{C} 4$ metabolite fluxes. Plant Physiol 148: 568-579.

[4] Cataldo, D. A., Maroon, M., Schrader, L. E. and Youngs, V. L. (1975) Cataldo, D. A., Maroon, M., Schrader, L. E. and Youngs, V. L. 1975. Rapid colorimetric determination of nitrate in plant-tissue by nitration a salicylic-acid. Commun Soil Sci Plan 6: 71-80. Commun Soil Sci Plan 6: 71-80.

[5] Choudhary, S.P., Yu, J.Q., Yamaguchi-Shinozaki, K., Shinozaki, K., Tran, L.S.P., 2012. Benefits of brassinosteroid crosstalk. Trends Plant Sci. 17: 594-605

[6] Fariduddin, Q., Yusuf, M., Ahmad, I., Ahmad, A., 2014. Brassinosteroids and their role in response of plants to abiotic stresses. Biol. Plant. 58, $9 \mathrm{e} 17$.

[7] Hasan, S.A., Hayat, S., Ahmad, A., 2011. Brassinosteroids protect photosynthetic machinery against the cadmium induced oxidative stress in two tomato cultivars. Chemosphere 84: 1446-1451.

[8] Hayat, S., Hasan, S.A., Yusuf, M., Hayat, Q., Ahmad, A., 2010. Effect of 28- homobrassinolide on photosynthesis, fluorescence and antioxidant system in the presence or absence of salinity and temperature in Vigna radiata. Environ. Exp. Bot. 69: 105-112.

[9] Herdina, J.H.Silsbury, October 1990. Growth, nitrogen accumulation and partitioning, and N2 fixation in faba bean (Vicia faba cv. Fiord) and pea (Pisum sativum cv. Early Dun), Field Crops Research, Volume 24, Issues 3-4, Pages 173-188.

[10] Hoglind, M., Hanslin, H.M., Mortensen, L.M., 2011. Photosynthesis of $€$ Lolium perenne L. at low temperatures under low irradiances. Environ. Exp. Bot. 70: 297-304.

[11] Hu, W.H., Yan, X.H., Xiao, Y.A., Zeng, J.J., Qi, H.J., Ogweno, J.O., 2013. 24- epibrassinosteroid alleviate drought-induced inhibition of photosynthesis in Capsicum annuum. Sci. Hortic. 150: 232-237.

[12] Jaworski, E.G. (1971) Nitrate Reductase Assay in Intact Plant Tissues. Biochemical and Biophysical Research Communications, 43:1274-1279.

[13] Kagale, S., Divi, U.K., Krochko, J.E., Keller, W.A., Krishna, P., 2007 Brassinosteroid confers tolerance in Arabidopsis thaliana and Brassica napus to a range of abiotic stresses. Planta 225: 353-364.

[14] Liu J, Gao H, Wang X, Zheng Q, Wang C, Wang X, Wang Q. 2014.Effects of 24-epibrassinolide on plant growth, osmotic regulation and ion homeostasis of salt-stressed canola. Plant Biol; 16:440-450.

[15] Liu, J., Gao, H., Wang, X., Zheng, Q., Wang, C., Wang, X., Wang, Q. 2014. Effects of 24- epibrassinolide on plant growth, osmotic regulation and ion homeostasis of salt-stressed canola. Plant Biol. 16: 440-450.

[16] Loulakakis, K.A. 1997. Genomic organization and expression of Osmotic -like gene in Vitis vinifera L. Vitis 36; 157-158Loubser, J.T. and A.J. Meyer 1990. Dual cultures of Meloidogyne javanica and grapevine rootastock on artificial media. South Afr. J. Enol. Vitic. 11:42-45.

[17] Miflin, B.J. 1967. Distribution of nitrate and nitrite reductase in barley, Nature 214: 1133-1134.

[18] Müssig, C., 2005. Brassinosteroid-promoted growth. Plant Biol. 7, $110 \mathrm{e} 117$.

[19] Ogawa S, Tank DW, Menon R, Ellermann JM, Kim SG, Merkle H, Ugurbil K. (1992)Intrinsic signal changes accompanying sensory stimulation: functional brain mapping with magnetic resonance imaging. Proc Natl Acad Sci U S A.89: 5951-5955

[20] O'NEAL, D. \& Joy, K. W. 1974. Glutamine synthetase of pea leaves. Plant Physiology, 54: 773-79. 
[21] Sadasivam, S. and Manickam, A.1992. Biochemical Methods for Agricultural Sciences. Wiley Eastern Ltd., New Delhi.

[22] Shu S, Tang Y, Yuan Y, Sun J, Zhong M, Guo S. 2016.The role of 24-epibrassinolide in the regulation of photosynthetic characteristics and nitrogen metabolism of tomato seedlings under a combined low temperature and weak light stress. Plant Physiol Biochem; 107:344-353.

[23] Song YL, Dong YJ, Tian XY, Kong J, Bai XY, Xu LL, He ZL. 2016. Role of foliar application of 24-epibrassinolide in response of peanut seedlings to iron deficiency. Biol Plant:;60:1-14.

[24] Srivastava HS, Singh RP .1987.Role and regulation of L-glutamate dehydrogenase activity in higher plants. Phytochemistry $26: 597-610$.

[25] Sun, J.L., Sui, X.L., Huang, H.Y., Wang, S.H., Wei, Y.X., Zhang, Z.X., 2014. Low light stress down-regulated rubisco gene expression and photosynthetic capacity during cucumber (Cucumis sativus L.) leaf development. J. Integr. Agric. 13:997-1007.

[26] Talaat NB.2013.24-Epibrassinolide alleviates salt-induced inhibition of productivity by increasing nutrients and compatible solutes accumulation and enhancing antioxidant system in wheat (Triticum aestivum L.) Acta Physiol Plant. 35:729-740.

[27] Yuan, G.F., Jia, C.G., Zhen, L., Sun, B., Zhang, L.P., Liu, N., Wang, Q.M., 2010. Effect of brassinosteroids on drought resistance and abscisic acid concentration in tomato under water stress. Sci. Hortic. 126: 103-108.

[28] Yuan, L.Y., Shu, S., Sun, J., Guo, S.R., Tezuka, T., 2012. Effects of 24-epibrassinolide on the photosynthetic characteristics, antioxidant system, and chloroplast ultrastructure in Cucumis sativus L. under Ca(NO3)2 stress. Photosynth. Res. 11: 205-214. 